\title{
O impacto da digitalização do rádio na opinião dos jornalistas e dos ouvintes:
}

\section{The impact of digitization of radio in the opinion of journalists and listeners}

Nair Prata I nairprata@uol.com.br

Doutora em Linguística Aplicada pela UFMG, professora do curso de Jornalismo da Universidade Federal de Ouro Preto (UFOP) e coordenadora do Grupo de Pesquisa Rádio e Mídia Sonora da Sociedade Brasileira de Estudos Interdisciplinares da Comunicação (Intercom).

Maria Cláudia Santos I mariaclaudiasantos@yahoo.com.br Jornalista, mestre em Gestão Social e Desenvolvimento Local (UNA), coordenadora de jornalismo da Rádio Itatiaia (MG) e correspondente internacional para a Rádio Voz da América (VOA-EUA).

Wanir Campelo I wanircampelo@gmail.com Mestre em Comunicação pela Universidade São Marcos (SP), jornalista, professora do curso de Jornalismo do Centro Universitário de Belo Horizonte e assessora de imprensa do secretário de Estado de Governo de Minas Gerais.

Sônia Caldas Pessoa I soniacaldaspessoa@gmail.com Jornalista, mestre e doutoranda em Linguística (UFMG), professora da Universidade Federal de Ouro Preto (UFOP) e do Centro Universitário Newton Paiva.

\section{Resumo}

O Brasil prepara-se para receber o rádio digital, mas as discussões acerca da nova mídia são marcadas, principalmente, pelos aspectos tecnológicos; pouco se debate sobre a produção de conteúdo, as novas formas de jornalismo e o que o público espera desse novo modelo. Há três anos, foi realizada pesquisa com ouvintes e jornalistas da Rádio Itatiaia, com o objetivo de conhecer a opiniáo deles no que diz respeito ao impacto do processo de digitalização. Em 2011, a pesquisa foi reaplicada. Os resultados mostram que há um novo público e que as emissoras devem se apressar, senão o digital já nasce obsoleto.

Palavras-Chave: Rádio digital; Jornalistas; Público; Rádio Itatiaia.

\begin{abstract}
Brazil is preparing to receive digital radio, but the discussions about the new media are marked main-ly by the technological aspects; there is little debate on the content production, new forms of journal-ism and what the public expects of this new model. Three years ago, a research was conducted with listeners and journalists from Radio Itatiaia to know their opinion regarding the impact of the digital process. In 2011, the research was reapplied. The results show that there is a new audience and that radio stations should hurry to prevent the digital born already obsolete.
\end{abstract}

Keywords: Digital radio; Journalists; Audience; Itatiaia Radio. 


\section{Introdução}

As emissoras de rádio brasileiras estão se preparando para ingressar, definitivamente, na era digital, com as consequentes mudanças e adequaçóes aos processos de produção e de transmissão dos conteúdos jornalísticos. Uma dessas emissoras é a Rádio Itatiaia, uma das maiores estaçôes do Brasil, com índices importantes de audiência, de fidelidade do público e em processo de digitalização, com transmissão on-line pela internet. Dois sujeitos, principalmente, devem ser avaliados nesta transição: os jornalistas, responsáveis pela produção do novo conteúdo em meio digital e o público, receptor dos novos produtos.

O presente trabalho parte de duas pesquisas realizadas anteriormente. Num trabalho intitulado "Enfim, o digital: expectativas dos ouvintes da Itatiaia diante da chegada do novo rádio" (PRATA, CAMPELO e SANTOS, 2008a) foi feito um levantamento sobre as expectativas dos ouvintes da Itatiaia diante da chegada da digitalização. Paralelamente, foi realizada pesquisa intitulada "O impacto da digitalização no processo de produção das notícias radiofônicas, segundo os jornalistas da Rádio Itatiaia” (PRATA, CAMPELO e SANTOS, 2008b), com o objetivo de conhecer o modo como os jornalistas da emissora avaliavam o processo de digitalização e quais as suas expectativas diante do cenário de um novo modelo de rádio.

Agora, três anos depois dessas pesquisas, voltamos a fazer nova investigação, propondo as mesmas perguntas, tanto aos jornalistas quanto aos ouvintes da Rádio Itatiaia, com o objetivo de conhecer a situação atual e traçar um quadro comparativo, já que a digitalização é um processo evolutivo que envolve, principalmente, pessoas, tanto as produtoras quanto as receptoras. O resultado é muito interessante.

\section{A digitalização das emissoras de rádio}

Em todo o mundo, há uma intensa movimentação em torno do rádio digital e das novidades que essa tecnologia traz consigo. Questôes como linguagem, preço do aparelho receptor, readequação do trabalho do jornalista e novas formas de interação com o público, entre muitas outras, são debatidas pela sociedade, pelos profissionais de comunicação e nas redaçóes das emissoras de rádio. São conhecidos hoje três sistemas de transmissão de rádio digital:

1. DAB (Digital Audio Broadcasting): É constituído de duas variaçôes, uma para cada serviço: o DAB para FM e o DRM (Digital Radio Mondiale) para AM.

2. IBOC (In-Band On Channel): Pode ser utilizado tanto para FM quanto AM, por via terrestre ou por satélite, nas atuais frequências, sem faixas adicionais e transmitindo áudio e dados simultaneamente, permitindo às emissoras se digitalizarem com um processo rápido e simples de migração.

3. ISDB (Integrated Services Digital Broadcast): Sistema japonês, é considerado uma convergência tecnológica de rádio com TV digital. 
No Brasil, depois de dez anos de debate, ainda não foi definido o padrão de rádio digital a ser utilizado, apesar de uma portaria do Ministério das Comunicaçôes ter implantado, em 30 de março de 2010, o Sistema Brasileiro de Rádio Digital.

Quando se fala em rádio digital, a explicação mais comum é: "AM com som de FM e FM com som de CD". Mas, além de um som com alta qualidade, as novidades do rádio digital prometem ser muito maiores, principalmente no aspecto da linguagem. A grande mudança deve residir, sem dúvida alguma, no tocante à possibilidade de interaçáo com o ouvinte, através da criaçáo de novos canais de comunicação. Candelas (2001) explica que estamos entrando numa fase em que há outra forma de entender o rádio. Segundo o autor, o mundo do rádio digital é o rádio de conteúdos especializados, mas a questão principal que se coloca é sobre o grau de aceitação dessas novas rádios por parte dos usuários.

Outra face da digitalização é a transmissão de rádio via internet. Com o advento da web, empresas brasileiras em geral criaram seus sites para uma interface com o consumidor e, aos poucos, as rádios também passaram a ofertar a transmissão on-line. A partir de 1998, foram criadas, no Brasil, emissoras de rádio com existência apenas na internet, as webradios.

\section{O papel do jornalista na era digital}

A internet, indiscutivelmente, vem provocando profundas mudanças no campo da Comunicação e, no Jornalismo, também são muitas as transformaçôes. Há, em todo o mundo, um crescente abandono dos processos analógicos. Não é possível afirmar, no entanto, que o produto jornalístico seja melhor agora, mas é incontestável que a web proporcionou transformaçóes profundas nas redaçôes e no trabalho.

Torres (2004) defende que as mudanças provocadas pela internet manifestam-se principalmente em três áreas: nas relações humanas, no aperfeiçoamento do trabalho e na redução de tempo e dinheiro (p. 35). Vivar e Arruti (2001) falam que novos elementos, conceitos e definiçóes passam a ser usados no mundo do jornalismo, a partir do advento da web. Os autores explicam, ainda, que o processo de informatizaçáo do jornalismo passou por duas fases. A primeira foi a informatização do processo produtivo, isto é, as redaçôes foram informatizadas, mas o suporte final continuou sendo o papel. A segunda fase foi a informatização do produto, com o suporte passando a ser o computador. Os autores lembram que essa fase não está presente ainda em toda a imprensa.

Noci e Ayerdi (1999) também abordam vantagens e desvantagens, ao determinarem as características do novo produto eletrônico surgido a partir das modernas tecnologias. Como pontos positivos, o novo produto é digital, multimídia, interativo, apresenta ruptura da sequencialidade, tem a possibilidade de acúmulo de informaçôes e é virtual. No entanto, há também inconvenientes e problemas: saturação da informação, perda e desorientação, ausência de hierarquização e, como consequência de tudo isso, perda de credibilidade. É importante a configuração dessa ambiguidade do novo produto, pois se há aqueles que somente o enxergam coroado de benesses, há, no entanto, os que o 
avaliam como o fim dos tempos. Certamente que esse novo produto não pode ser encaixado em nenhum dos extremos, mas como algo novo que ainda tenta encontrar o próprio caminho.

\section{A Rádio Itatiaia na era digital}

A Rádio Itatiaia, sediada em Belo Horizonte (MG), é uma empresa particular, fundada em 1951, sem ligaçáo com grupos religiosos ou políticos, de administração familiar, forte tradição esportiva e programação baseada no tripé: jornalismo, esporte e prestação de serviços. Atualmente é transmitida, simultaneamente, em AM (610) e FM (95,7). Via satélite, atinge 90\% das cidades mineiras, além de poder ser ouvida em tempo real na internet pelo endereço http://www.itatiaia.com.br.

A emissora se consolidou no cenário radiofônico mineiro, na década de 70 , e no final dos anos 80 , conseguiu chegar ao primeiro lugar de audiência. Desde então, apresenta números expressivos como o primeiro lugar de audiência nas classes A e B, além de manter $69,9 \%$ dos ouvintes de AM sintonizados em sua frequência. A emissora conta com $94,5 \%$ de audiência nas transmissóes esportivas.

A Rádio Itatiaia é dona de uma das maiores matrizes de áudio instaladas atualmente em emissoras de rádio do Brasil e, seguindo essa trajetória, promete contar com o processo inteiramente digital, da produçáo à transmissão, assim que o governo definir o padrão técnico brasileiro. $\mathrm{O}$ processo de digitalização na Itatiaia começou em 2000, com a transmissão, via equipamentos digitais, dos Jogos Olímpicos de Sydney. Em 2002, os Departamentos de Esportes e Jornalismo substituíram o processo de edição linear, pelo não-linear, feito em computadores. Atualmente, a emissora usa equipamentos digitais para transmissóes de eventos ex-ternos, como coberturas internacionais e transmissóes de centros de treinamentos esportivos. Nos departamentos de jornalismo e esportes, todas as gravaçóes são feitas em aparelhos digitais. Gravaçóes que, depois, passam por edição feita em computador, utilizando softwares como o Sound Forge. Além disso, a emissora conta com processadores e links digitais e, há dois anos, investiu na instalação de transmissores digitais para a FM e na adaptação do Centro de Transmissão AM para um sistema já adequado para futura instalação do rádio digital.

\section{Procedimentos metodológicos}

O primeiro levantamento, realizado em julho de 2008, foi feito por meio de um questionário composto por 22 perguntas abertas e fechadas, relacionadas ao impacto da digitalização no processo de produção das notícias radiofônicas. Dos 34 questionários entregues aos jornalistas e estagiários do Departamento de Jornalismo da emissora, 28 foram respondidos. A maioria dos respondentes era homens (53,57\%), com idades variando entre 21 e 51 anos. Em 2011, segunda fase da pesquisa, dos 34 integrantes do Departamento de Jornalismo, 17 responderam ao convite para a participação na pesquisa, respondendo um questionário igual ao aplicado há três anos. A maioria dos pesquisados, desta vez, era mulheres $(52,94 \%)$, com idades variando entre 22 e 54 anos. 


\begin{tabular}{|c|c|c|}
\hline Pesquisados & $\mathbf{2 0 0 8}$ & $\mathbf{2 0 1 1}$ \\
\hline Respondentes & $28(21$ a 51 anos $)$ & 17 (22 a 54 anos) \\
\hline Sexo feminino & $46,43 \%$ & $52,94 \%$ \\
\hline Sexo masculino & $53,57 \%$ & $47,06 \%$ \\
\hline
\end{tabular}

Já a escolha do tipo de abordagem com o ouvinte recaiu sobre a entrevista padronizada ou estruturada. Para definir a amostra a ser pesquisada, optou-se pelo público voluntário. A partir daí, elaborou-se o seguinte texto-convite, veiculado na programaçáo da emissora: "Um grupo de pesquisa quer saber o que os ouvintes pensam sobre o rádio digital. Este grupo quer ouvir, até mesmo, quem não sabe nada sobre o assunto. Os interessados em participar desta pesquisa devem enviar e-mail para pesquisaitatiaia@yahoo.com.br dizendo que querem participar. Depois, essas pessoas vão receber um pequeno questionário para responder".

No caso da pesquisa com ouvintes, na primeira fase do estudo em 2008, 117 ouvintes aceitaram o convite divulgado durante a programaçáo da emissora, de 19 a 22 de julho, no horário entre 09h00min e 18h00min. Na data limite para a devolução, 64 questionários haviam sido respondidos, o que corresponde a 54,7\%. Em 2011, 107 ouvintes aceitaram o convite divulgado, de 18 a 22 de julho, no horário entre $09 \mathrm{~h} 00 \mathrm{~min}$ e $18 \mathrm{~h} 00 \mathrm{~min}$. Do número total de interessados em participar do estudo, 81 devolveram os questionários preenchidos, o que corresponde a 75,7\%.

\begin{tabular}{|c|c|c|}
\hline Pesquisados & $\mathbf{2 0 0 8}$ & $\mathbf{2 0 1 1}$ \\
\hline Ouvintes que aceitaram o convite & 117 & 107 \\
\hline Número de questionários respondidos & $64(54,7 \%)$ & $81(75,7 \%)$ \\
\hline
\end{tabular}

\section{O jornalista diante das novas tecnologias em 2008 e 2011}

\section{A opiniáo dos jornalistas em 2008}

A grande maioria dos jornalistas pesquisados (85,7\%) acreditava que o papel do radio-jornalista diante das novas tecnologias já era bem diferente do jornalismo praticado no passado. Um entrevistado afirmou: "Foi preciso que, em curto prazo, nos adaptássemos à máquina, à internet, às ediçốes em rede, à linguagem. A informatização mudou o ritmo, agilizou, reciclou”.

Para cinco integrantes do Jornalismo da Itatiaia, que representam $17,9 \%$, operar a máquina foi o maior obstáculo, especialmente em relação aos softwares, mas para três respondentes (10,7\%), o mais difícil foi adaptar-se à linguagem. Sete pessoas, $25 \%$, recearam cometer erros e não ter como corrigi-los e oito, 28,6\%, tiveram dificuldade para dimensionar os novos conceitos de tempo e espaço. Cinco pessoas, $17,8 \%$, todas elas na faixa etária compreendida entre 21 e 30 anos, afirmaram que não tiveram dificuldades.

As mudanças na rotina da redação provocadas pelas novas tecnologias não foram percebidas por $14,28 \%$ dos respondentes, mas para $85,72 \%$ deles, muita coisa foi alterada. De acordo com 24 pessoas, não foram poucas as novidades que surgiram, especialmente no que diz respeito à "velocidade e qualidade da 
informação, à agilidade na apuração, à precisão dos fatos, à facilidade de acessar notícias do mundo inteiro, à modernização dos equipamentos utilizados, além de novas possibilidades criativas, da maior eficiência no trabalho, da facilidade para a edição técnica e da otimização do tempo", dentre outras.

Dos 28 participantes da pesquisa, apenas um jornalista do sexo masculino de 45 anos afirmou não estar adaptado às novas rotinas da redação ocorridas em função dos avanços tecnológicos. Três outros jornalistas do sexo masculino, com idades entre 36 e 51 anos, admitiram ter feito algum curso para utilizar as novas tecnologias. Quase 70\% dos respondentes percebem uma nova lógica na produçáo de conteúdo e acreditam que o radiojornalismo da era digital exige mais do profissional em termos de apuração do que o jornalismo praticado na era analógica. Contudo, as opiniôes se dividem de forma bastante equilibrada quando o assunto é a utilização da internet para a produção de uma reportagem: $47 \%$ acreditavam que ainda hoje é possível realizar esse trabalho desde a apuração, até à veiculação, sem precisar recorrer à web.

Quase 65\% dos entrevistados são favoráveis aos espaços que estão sendo abertos no radiojornalismo, para o chamado "jornalismo colaborativo", que permite a qualquer ouvinte repassar uma informação que ele mesmo tenha apurado; $61 \%$ acreditam que a digitalização possa oferecer um grau de interação plena entre ouvinte e produtor de conteúdo e $82,14 \%$ acham que o ouvinte irá intervir cada vez mais nas rotinas de produção do jornalismo radiofônico. No entanto, 86\% náo creem que o jornalista esteja caminhando para um papel de coadjuvante.

A quase totalidade dos respondentes - 96,42\% - acredita que, ao produzir conteúdo para a web ou para o rádio digital, estará construindo um novo produto advindo das modernas tecnologias com diferentes características. Para dar conta das exigências que têm surgido diante dessa nova realidade digital, 75\% dos respondentes afirmaram que os jornalistas precisam estar mais bem preparados para ingressar e/ou manter-se no mercado de trabalho, com cursos de especialização, aperfeiçoamento, além de conhecimentos de informática e línguas. Os outros $25 \%$ acreditam que esse aprendizado vai sendo construído na medida em que o profissional vai ganhando experiência no seu cotidiano. São muitas as expectativas dos jornalistas da Rádio Itatiaia diante das novas rotinas que começam a tomar conta das redaçóes com a implantação, em definitivo, das variadas tecnologias digitais. Um respondente afirmou: "Está nascendo o profissional multifuncional, ágil, criativo, atualizado, mais comprometido com a apuração dos fatos, adaptado aos novos equipamentos, preparado para trabalhar em rede e apto a realizar todas as funçóes jornalísticas: da produção à veiculação".

Para $85,7 \%$ dos respondentes, a produção do conteúdo jornalístico para o rádio melhorou diante das novas tecnologias, especialmente em função da quantidade de informaçóes a que se tem acesso atualmente. Uma jornalista, de 44 anos, no entanto, afirmou que nem tudo é assim tão positivo como parece aos olhos dos desavisados: "Percebo muitos profissionais acomodados com as informações instantâneas obtidas pela internet. Não se faz jornalismo só apurando via web. $\mathrm{O}$ rigor na apuração dos fatos precisa ser mantido a qualquer custo. Essa é a premissa básica para se fazer jornalismo, verdadeiramente”. 
Com relação ao jornalismo a ser praticado, especificamente, a partir da era digital, sete respondentes deixaram a questáo em branco ou disseram, simplesmente, não saber. Em compensação, os demais apontaram múltiplas expectativas do jornalismo da era digital: "mais qualidade, mais ágil e acessível a um número maior de pessoas, com informaçóes cada vez mais imediatas, rápidas e dinâmicas; interativo e mais próximo do ouvinte; mais ético, honesto, e de credibilidade, voltado para o interesse público e sem jabá1; direto, objetivo, prático, responsável, de acordo com o novo tempo, desafiador, competitivo e moderno".

\section{A opiniáo dos jornalistas em 2011}

$\mathrm{Na}$ segunda fase da pesquisa, realizada em julho de 2011, a maioria dos respondentes, $88,23 \%$, afirmou acreditar que o papel hoje do jornalista de rádio é bem diferente do jornalismo praticado pouco tempo atrás. Um jornalista afirmou: "O papel do jornalista de informar com qualidade e responsabilidade, visando o bem social, continua o mesmo. Mudam os procedimentos no processo de produção da notícia. Pesquisar e apurar se tornou mais rápido, mas ao mesmo tempo requer mais cuidado em relação à confiabilidade da fonte e também em relação à publicação de informaçôes”.

Diante da pergunta "Qual é ou foi a sua maior dificuldade na realização de suas funçóes, diante da necessidade de utilizar a tecnologia?", os respondentes se dividem, sendo duas as respostas mais citadas: cinco acham que é "dimensionar os novos conceitos de tempo e espaço" e cinco acreditam que é "o receio de cometer erros e não ter como corrigi-los". A totalidade dos respondentes afirma que percebeu mudanças na rotina da redação com a chegada das novas tecnologias. Algumas mudanças citadas: "Quando comecei a trabalhar em redação já dispunha de muita tecnologia. A novidade pra mim foi a chegada das redes sociais. Desde o Orkut até o Twitter, passando pelo Skype e o MSN”.

A quase totalidade dos jornalistas, 94,11\%, afirma estar adaptada às novas rotinas da redaçáo ocorridas em função dos avanços tecnológicos sem ter feito qualquer curso para utilizar as novas tecnologias. No entanto, mais da metade, $58,82 \%$, percebe alguma necessidade de ter que se adaptar a uma nova lógica de produção de conteúdo.

Os respondentes se dividem diante da questão: "Você acredita que o radiojornalismo da era digital exige mais do profissional em termos de apuração do que o radiojornalismo praticado na era analógica?": 52,94\% responderam que sim. No entanto, 12 respondentes, $70,58 \%$ do total, não acreditam que, atualmente, há quem ainda realize uma reportagem - da apuração à veiculação - sem a utilização da internet. Também a maior parte, $82,35 \%$ dos jornalistas, é favorável aos espaços que estão sendo abertos no rádio para o chamado jornalismo colaborativo, que permite a qualquer ouvinte repassar uma informação que ele mesmo tenha apurado. Mas a maioria dos participantes da pesquisa, $82,35 \%$, não acredita que o jornalista esteja caminhando para um papel de coadjuvante. $58,82 \%$ dos respondentes acreditam que a digitalizaçáo possa oferecer um grau de interatividade plena entre o ouvinte e os produtores de conteúdo. Para os participantes da pesquisa, o novo produto radiofônico terá características, que envolvem, principalmente, a linguagem. Uma opinião vale 
a pena ser destacada: "Não acredito que mude muito as principais características do rádio. $\mathrm{O}$ rádio é extremamente dinâmico. $\mathrm{O}$ que pode ser exigido é um maior uso de recursos de imagem na web".

Diante da nova realidade digital, o jornalista precisa, para 58,82\% dos respondentes, estar mais bem preparado para ingressar e/ou se manter no mercado de trabalho, com cursos de especialização e/ou aperfeiçoamento, além de conhecimentos básicos de internet e outras línguas. Para 94,11\% dos participantes, o ouvinte irá intervir cada vez mais nas rotinas de produção do jornalismo radiofônico. $\mathrm{Na}$ opiniáo dos respondentes, serão muitas as mudanças advindas no dia-a-dia das tarefas dos jornalistas a partir da implantação, em definitivo, das tecnologias digitais: "Acredito que a maior mudança será no tratamento com o ouvinte, uma vez que a participação deste, que já é muito utilizada, pode se tornar ainda maior".

Para 76,47\% dos respondentes, a produção de conteúdo jornalístico para o rádio melhorou com as novas tecnologias: "A instantaneidade em noticiar fatos é cada vez mais importante. E com a evolução tecnológica, podemos levar ao ouvinte a informação precisa com maior rapidez".

\section{Quadro: Opinião dos jornalistas}

\begin{tabular}{|c|c|c|}
\hline $\begin{array}{c}\text { A partir das novas } \\
\text { tecnologias }\end{array}$ & $\mathbf{2 0 0 8}$ & $\mathbf{2 0 1 1}$ \\
\hline $\begin{array}{c}\text { Papel do jornalista já é bem } \\
\text { diferente }\end{array}$ & $85,70 \%$ & $88,23 \%$ \\
\hline $\begin{array}{c}\text { Percepçáo da alteraçáo na } \\
\text { rotina de produção }\end{array}$ & $85,72 \%$ & $100 \%$ \\
\hline $\begin{array}{c}\text { Maior exigência do } \\
\text { profissional }\end{array}$ & $70 \%$ & $52,94 \%$ \\
\hline $\begin{array}{c}\text { Apoio ao jornalismo } \\
\text { colaborativo }\end{array}$ & $65 \%$ & $82,35 \%$ \\
\hline $\begin{array}{c}\text { Elevaçáo do grau de } \\
\text { interação }\end{array}$ & $61 \%$ & $58,82 \%$ \\
\hline $\begin{array}{c}\text { Aumento da intervençáo do } \\
\text { ouvinte nas rotinas }\end{array}$ & $82,14 \%$ & $94,11 \%$ \\
\hline $\begin{array}{c}\text { Jornalista ainda tem papel } \\
\text { principal }\end{array}$ & $86 \%$ & $82,35 \%$ \\
\hline Melhora na produçáo & $85,70 \%$ & $76,47 \%$ \\
\hline
\end{tabular}

\section{O ouvinte diante das novas tecnologias em 2008 e 2011}

\section{A opiniáo dos ouvintes em 2008}

A pesquisa feita com ouvintes foi dividida em duas partes, totalizando 29 perguntas, todas de múltipla escolha: 1) Sobre você (14 questóes) e 2) Sobre o rádio digital (15 questôes). A seguir, apresentamos a análise das respostas dos ouvintes.

A primeira parte da pesquisa, intitulada Sobre Você, mostrou que, dos 64 ouvintes que responderam ao questionário, a maioria é do sexo masculino (70\%) e com faixa etária predominante entre 21 e 30 anos (34,3\%). A renda 
mensal da metade dos respondentes é de até três salários mínimos, e ainda assim, mais de $70 \%$ declararam que moram em casa própria.

Somando-se o número de pessoas que concluíram o ensino médio ao número de pessoas que concluíram o ensino superior, o que se verifica é uma alta porcentagem no grau de instrução, que chega bem próxima a 90\%. Também é relevante a quantidade de fontes utilizadas para a busca de informação. Os 64 entrevistados disseram que utilizam uma ou mais de uma fonte de informação diariamente. A mídia rádio foi, sem dúvida, a mais citada: 96,8\% dos entrevistados disseram que se informam pelo rádio, mas a televisão e a internet também foram lembradas pela maioria deles.

A busca pela informação nos meios de comunicação é bastante diversificada e, no caso do rádio, apenas uma pessoa declarou náo ouvi-lo todos os dias. Além disso, mais de $60 \%$ têm o rádio como companhia por mais de três horas diárias. Menos da metade dos respondentes, 46,8\%, ouve rádio pela internet. Desse total, apenas um terço o faz diariamente e a maioria, por até três horas, no máximo.

$\mathrm{Na}$ segunda parte da pesquisa, intitulada Sobre o rádio digital, o que se percebe é que, dos 64 ouvintes que responderam ao questionário, 31 disseram saber o que é o rádio digital, enquanto 33 disseram desconhecê-lo. Ainda assim, mesmo aqueles que não sabem o que é o digital, não se furtaram a responder a todas, ou a quase todas as questóes relacionadas ao assunto.

A maior parte $(40,6 \%)$ dos respondentes está otimista em relação à implantaçáo dessa tecnologia no Brasil ainda no ano da pesquisa. Para a metade deles, o aparelho de rádio para a transmissão digital deverá ser semelhante ao analógico e todos apostam em equipamentos portáteis: 31 ouvintes acreditam que haverá um visor na frente do rádio, como uma tela de telefone celular, por onde também irão receber outros tipos de informação. Dos 64 participantes da pesquisa, 49 (76,5\%) disseram que comprariam um rádio digital para obter informaçóes escritas em uma tela, como a previsáo do tempo, a cotação do dólar, e até mesmo o nome do cantor cuja música estivesse no ar naquele momento. Além disso, 54,6\% afirmaram que comprariam um rádio digital para receber clipes de seus cantores favoritos.

Os participantes da pesquisa também prometem não medir esforços financeiros para adquirir um aparelho que lhes permita ouvir o rádio digitalmente. Quase 78\% afirmaram que pagariam até $\mathrm{R} \$ 300,00$ para comprar um rádio digital. Um respondente afirmou que estaria disposto a pagar mais de $\mathrm{R} \$$ 1.000.00 para receber as transmissóes digitais. Por outro lado, nove ouvintes disseram que náo pagariam nenhum valor a mais para adquiri o aparelho digi-tal, por não encontrarem vantagem nessa tecnologia.

A interatividade é a grande esperança dos ouvintes quando o tema é o conteúdo para o rádio digital: 47 dos 64 que colaboraram com a pesquisa acreditavam que teriam oportunidade de participar ativamente da programação das emissoras. Quase 94\% dos ouvintes acreditavam que poderiam participar dos programas do rádio digital mandando mensagens e recebendo a resposta no ar, 
em tempo real. Já a música segmentada no digital divide opiniōes: 46,8\% dos ouvintes responderam que ouviriam uma emissora que tocasse exclusivamente um tipo de música, enquanto $53.1 \%$ disseram que não ouviriam uma emissora com esse perfil. Os gêneros musicais escolhidos pelos ouvintes foram os mais diversificados. A MPB foi citada 34 vezes, o rock, 28 e a música sertaneja, 16 vezes.

Emissoras especializadas em política e esportes foram citadas 33 vezes cada uma, quando a pergunta apresentada foi "Você compraria um rádio digital para ouvir emissoras especializadas em quê?”. Quando a questão está diretamente ligada ao Jornalismo, o que se percebe é o grande interesse pela informação: $84,3 \%$ desejam receber notícias específicas pelo rádio digital e quase um terço dos respondentes espera que as notícias possam ser mais detalhadas. A expectativa dos ouvintes com relação às mudanças na parte jornalística é bastante significativa e atinge 79,6\% dos entrevistados.

\section{A opiniáo dos ouvintes em 2011}

Três anos depois da primeira pesquisa, 81 ouvintes responderam as questóes, mais de $80 \%$ acima de 31 anos de idade e $72,15 \%$ do sexo masculino. A escolaridade do público respondente é a seguinte: $97,5 \%$ têm pelo menos o Ensino Médio, sendo que $16,46 \%$ são pós-graduados. O público participante da pesquisa apresenta ainda o seguinte perfil: $48,1 \%$ são casados; $76,54 \%$ nasceram em Belo Horizonte; $67,9 \%$ moram em residência própria; $87,65 \%$ têm atividade remunerada e quase a metade $(41,56 \%)$ ganha até três salários mínimos. Apenas 10,39\% ganham mais de dez salários mínimos. Os ouvintes se informam, principalmente, pela internet $(22,88 \%)$ e rádio $(22,57 \%)$. O público participante ouve rádio todos os dias $(90,12 \%)$, de três a seis horas por dia (37,04\%). Ouvem rádio pela internet $67,9 \%$ dos participantes, sendo que $45,76 \%$ fazem isso todos os dias.

Sobre a chegada do rádio digital, apenas $18,18 \%$ acreditam que a nova tecnologia virá ainda este ano. Mais da metade (51,85\%) afirmam saber o que é o rádio digital. A partir da questão "Como será o aparelho de rádio digital?", $72,84 \%$ dos respondentes disseram que será "com uma tela na frente, parecendo um celular". Apenas 17,28\%, ou seja, 14 ouvintes, acreditam que o novo rádio será como os aparelhos de hoje. A pergunta "Até quanto você pagaria hoje para ter um rádio digital?", 44,3\% responderam que pagariam, no máximo, 100 reais e nenhum ouvinte pagaria mil reais ou mais, como em 2008.

Sobre as expectativas em relação ao novo rádio, 50,38\% querem interatividade total; 20,61\% desejam notícias mais detalhadas e 15,2\% apostam em programas de variedades em que haja possibilidade de conversar com quem está nos estúdios. A quase totalidade dos respondentes, 95,06\%, se interessaria em ouvir notícias específicas no rádio digital. Já quanto à música, os ouvintes se dividem: pouco mais da metade $(52,62 \%)$ ouviria uma emissora que só tocasse um tipo de música, a outra metade não se interessaria por este tipo de emissora. E, quando o assunto é música, os gêneros preferidos pelo público participante da pesquisa, para uma programação exclusiva no novo rádio, são: $\mathrm{MPB}(22,7 \%)$, rock $(22,7 \%)$, samba $(10,81 \%)$ e sertaneja $(8,11 \%)$. Quanto à segmentação das emissoras digitais, as preferências dos respondentes recaem sobre as rádios especializadas em economia (17,73\%), esportes $(25,62 \%)$ e política $(23,65 \%)$. 
A maioria dos respondentes, 90,12\%, afirma que compraria um aparelho de rádio digital para ter informaçóes escritas em uma tela, como a previsão do tempo, a cotação do dólar, o nome do cantor cuja música estivesse no ar no momento da audição. Os ouvintes também acreditam (83,54\%) que poderão participar dos programas do rádio digital mandando mensagens e recebendo a resposta no ar, em tempo real. A maioria $(72,22 \%)$ também crê que o rádio digital, no futuro, poderá transmitir imagens.

As opinióes dos ouvintes se dividem quando o assunto é comprar um rádio digital para receber clipes de seu cantor preferido: apenas a metade dos respondentes arcaria com esta despesa. Também para a possibilidade de pagamento por canais especializados em programas específicos as opinióes se dividem: pouco mais da metade $(51,85 \%)$ não faria este gasto. No entanto, diante da pergunta "Você acredita que o jornalismo no rádio vai mudar com a chegada do digital?", a maior parte (87,34\%) respondeu que sim.

\section{Quadro: opiniáo dos ouvintes}

\begin{tabular}{|c|c|c|}
\hline Expectativa rádio digital & $\mathbf{2 0 0 8}$ & $\mathbf{2 0 1 1}$ \\
\hline Sabe o que é rádio digital & $48,43 \%$ & $51,85 \%$ \\
\hline Quanto pagaria pelo rádio digital & $78 \%$ - até $\mathrm{R} \$ 300,00$ & $44,3 \%$ - até $\mathrm{R} \$ 100,00$ \\
\hline $\begin{array}{c}\text { Jornalismo vai mudar com a che- } \\
\text { gada do novo rádio }\end{array}$ & $79,6 \%$ & $87,34 \%$ \\
\hline $\begin{array}{c}\text { Interatividade vai aumentar com o } \\
\text { rádio digital }\end{array}$ & $73,43 \%$ & $18,18 \%$ \\
\hline $\begin{array}{c}\text { Crença na implantação da nova } \\
\text { tecnologia no ano da pesquisa }\end{array}$ & $40,6 \%$ & $50 \%$ \\
\hline $\begin{array}{c}\text { Compraria o rádio digital p/ rece- } \\
\text { ber músicas favoritas }\end{array}$ & $54,6 \%$ & $90,12 \%$ \\
\hline $\begin{array}{c}\text { Compraria o rádio digital p/ ter } \\
\text { informação na tela }\end{array}$ & $76,5 \%$ & $95,06 \%$ \\
\hline $\begin{array}{c}\text { Gostaria de ter notícia específica } \\
\text { pelo rádio digital }\end{array}$ & $84,3 \%$ & $83 \%$ \\
\hline
\end{tabular}

\section{Considerações finais}

Os ouvintes parecem vislumbrar um modelo de rádio digital ao sonhar com um conteúdo diferente dos moldes atuais aos quais estão acostumados. Fica claro, pela pesquisa, que o público está diminuindo as expectativas em relação ao digital, independentemente da inovação tecnológica em si. Hoje, o público conhece mais a internet e o rádio digital e suas novidades podem até mesmo parecer ultrapassadas aos olhos de quem já se adaptou às novas tecno-logias. O número de ouvintes participantes da pesquisa, feita pela internet, foi maior em 2011 do que em 2008 e as diferenças não param por aí. Enquanto em 2008 o principal meio de informação dos ouvintes era o rádio (96,8\%), em 2011, esse número caiu assustadoramente (22,57\%), perdendo espaço para a internet. Também agora o público que ouve rádio pela web é maior. Em 2008, menos da metade dos ouvintes tinha esse costume (46,8\%). Agora $67,9 \%$ ouvem rádio pela web. É superior, ainda, o número de respondentes que sabem 
o que seja o rádio digital, mas cai o número de ouvintes que pagariam até $\mathrm{R} \$$ 300,00 por um novo aparelho e ninguém daria $\mathrm{R} \$ 1.000,00$ ou mais por um rádio com recepção digital.

\begin{tabular}{|c|c|c|}
\hline Rádio X Internet & $\mathbf{2 0 0 8}$ & $\mathbf{2 0 1 1}$ \\
\hline O Rádio como o principal meio de informação dos ouvintes & $96,8 \%$ & $22,57 \%$ \\
\hline Ouvintes que ouvem rádio pela web & $46,8 \%$ & $64 \%$ \\
\hline
\end{tabular}

Pela pesquisa realizada, percebe-se uma grande vontade dos ouvintes da Itatiaia em tornarem-se, também, produtores de conteúdo, realizando o trabalho que, por direito, pertence aos profissionais que cursaram a faculdade de Jornalismo. Mas será esta a tendência da mídia como um todo? Ou as discussōes a respeito desse tema já se esgotaram?

De qualquer forma, é importante que o governo, as emissoras e os jornalistas se deem conta de que não basta a simples definição por um padrão técnico para a implantação do rádio digital no Brasil. É necessária a adoção de uma nova mentalidade e de novos processos regidos pela digitalização, com a consequente opção por um jornalismo que atenda aos anseios do público. De outra forma, o rádio digital já nasce condenado ao fracasso.

É preciso, ainda, um olhar acurado sobre o sujeito que será o grande responsável pela quebra do paradigma analógico, com a consequente adesão ao digital: o jornalista. Pelas mãos desse profissional é que se dará a verdadeira revolução. Apesar do menor número de jornalistas participantes da pesquisa em 2011, há notadamente um equilíbrio entre o conteúdo das respostas há três anos e agora.

Pela pesquisa realizada para este trabalho, percebe-se um paradoxo. Se, por um lado, o jornalista da Itatiaia sabe que está diante de um novo produto digital, com as características intrínsecas às novas tecnologias, por outro lado não tem a certeza de que isso lhe proporcionará melhores condiçôes de trabalho, com aumento da remuneração e valorização profissional.

A presente investigação mostra que os jornalistas sabem que são os construtores de um novo produto digital, mas manifestam certa nostalgia dos processos analógicos de produçáo e alguns até temem que as novas tecnologias tirem o rigor do jornalismo radiofônico.

Pesa sobre a Rádio Itatiaia a responsabilidade pela construção de um novo modelo calcado nas novas tecnologias e, inclusive, um jornalista entrevistado pela pesquisa fala isso, ao afirmar que a Itatiaia tem tradição de inovação e pioneirismo nos seus 56 anos e isso se deve confirmar, mais uma vez, com a era digital. A Itatiaia é assim: uma grande emissora que fala de um jeito que todos os mineiros entendem, sem perder o seu foco e, principalmente, a sua ousadia.

Esse novo modelo, certamente, tendo como timoneiro o jornalista, deve contemplar a adoção, em definitivo, da digitalização de todos os processos de produção e transmissão da emissora, além de uma página na internet que priorize a interface com o público, possibilitando ao ouvinte novas formas de interação e produção de conteúdos. 
Os radiodifusores, realmente, parecem não estar pensando em conteúdo, quando o assunto é o rádio digital. Por enquanto, só conseguem dar atenção para os entraves e possibilidades do ponto de vista técnico. As emissoras, entretanto, não vão poder demorar muito, pois, assim que a questão técnica estiver superada, terão que se deparar com um problema provavelmente muito maior do que a escolha do sistema de transmissáo do rádio digital entre o IBOC e o DAB: a pressão do público por novos conteúdos, com as necessárias adaptaçôes e o desenvolvimento de novos produtos para o rádio digital.

\section{Referências bibliográficas}

CANDELAS, Leopoldo Seijas. Los sistemas informativos en la era digital. Madrid: Editorial Universitas, 2001.

NOCI, Javier Díaz e AYERDI, Koldo Meso. Periodismo en Internet Modelos de la prensa digital. Madrid: Universidad del País Vasco, 1999.

PRATA, Nair; CAMPELO, Wanir e SANTOS, Maria Cláudia. Enfim, o digital: expectativas dos ouvintes da Itatiaia diante da chegada do novo rádio. Anais do VI Encontro Nacional dos Pesquisadores em Jornalismo, São Bernardo do Campo, São Paulo, 2008a.

- O impacto da digitalização no processo de produção das notícias radiofônicas, segundo os jornalistas da Rádio Itatiaia. Anais do IX Congreso Latino Americano de Investigación de la Comunicación, México, 2008b.

TORRES, Maria Bella Palomo. El periodista on line: de la revolución a la evolución. Sevilla: Comunicación Social Ediciones y Publicaciones, 2004.

VIVAR, Jesus Flores e ARRUTI, Alberto Miguel. Ciberperiodismo Nuevos enfoques, conceptos y profesiones emergentes en el mundo infodigital. Madrid: Ediciones 2010, 2001.

\section{Notas}

1. Jabá (ou jabaculê) é o nome dado à troca de favores entre a emissora de rádio e pessoas ou empresas, geralmente envolvendo negociaçóes financeiras. 